Primljen / Received: 21.1.2013.

Ispravljen / Corrected: 9.8.2013.

Prihvaćen / Accepted: 10.9.2013.

Dostupno online / Available online: 10.10.2013.

\title{
Special purpose concrete products from waste tyre recyclates
}

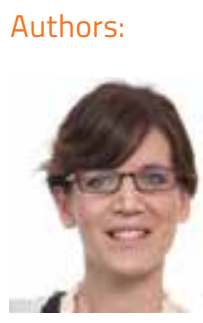

Marijana Serdar, PhD. CE

University of Zagreb

Faculty of Civil Engineering

mserdar@grad.hr

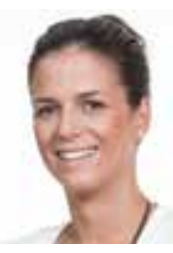

Ana Baričević, B.Sc. CE

University of Zagreb

Faculty of Civil Engineering

abaricevic@grad.hr

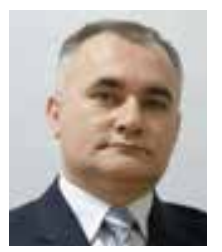

Prof. Stjepan Lakušić, PhD. CE

University of Zagreb

Faculty of Civil Engineering

laki@grad.hr

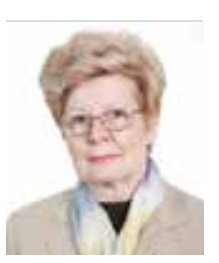

Prof. Dubravka Bjegović, PhD. CE

University of Zagreb

Faculty of Civil Engineering

dubravka@grad.hr

\section{Marijana Serdar, Ana Baričević, Stjepan Lakušić, Dubravka Bjegović}

\section{Special purpose concrete products from waste tyre recyclates}

The ways in which concrete properties are influenced by waste tyre recyclates, used as secondary raw materials, are presented in the paper. Taking advantage of these properties, several special-purpose construction products, containing raw materials obtained by tyre recycling, have been developed at the Faculty of Civil Engineering, University of Zagreb. Each of these innovative products represents an environment-friendly, functional and cost-effective alternative to products traditionally used in engineering practice.

\section{Key words:}

recycling, waste tyres, noise barriers, sound absorption, ductility, fiber reinforced concrete

\section{Marijana Serdar, Ana Baričević, Stjepan Lakušić, Dubravka Bjegović}

Izvorni znanstveni rad

\section{Betonski proizvodi specijalne namjene od reciklata otpadnih guma}

U radu je prikazano kako reciklati otpadnih guma, upotrijebljeni kao sekundarne sirovine, utječu na svojstva betona. S obzirom na dobivena svojstva, na Građevinskom fakultetu Sveučilišta u Zagrebu osmišljeni su gradevni proizvodi za specijalne namjene, koji u svom sastavu sadržavaju sirovine dobivene recikliranjem guma. Svaki od navedenih inovativnih proizvoda predstavlja ekološki, funkcionalno i ekonomski konkurentnu alternativu uobičajeno korištenim proizvodima u inženjerskoj praksi.

Ključne riječi:

reciklaža, otpadne gume, barijere, apsorpcija zvuka, žilavost, mikroarmirani betoni

Wissenschaftlicher Originalbeitrag

Marijana Serdar, Ana Baričević, Stjepan Lakušić, Dubravka Bjegović

\section{Betonprodukte aus rezyklierten Altreifen für spezielle Anwendungen}

In der vorliegenden Arbeit ist dargestellt wie Rezyklate aus Altreifen, als sekundäre Rohstoffe angewandt, auf Betoneigenschaften einwirken. In Bezug auf die erhaltenen Eigenschaften sind an der Fakultät für Bauwesen der Universität in Zagreb Bauprodukte für spezielle Anwendungen erdacht worden, die unter anderem aus durch das Rezyklieren von Altreifen gewonnenen Rohstoffen zusammengesetzt sind. Jedes dieser innovativen Produkte stellt eine ökologisch, funktionell und ökonomisch wettbewerbsfähige Alternative zu herkömmlich in der Baupraxis angewandten Produkten dar.

\section{Schlüsselwörter:}

Rezyklieren, Altreifen, Barriere, Schallabsorption, Duktilität, mikroarmierter Beton 


\section{Introduction}

Extensive use of tyres in car industry has resulted in accumulation of large quantities of used tyres that have to be disposed of at the end of their useful life. As many as 1.5 billon of tyres are produced worldwide each year for the automobile industry, and almost 3.5 million tons of waste tyres are generated in the EU countries alone [1]. According to the Directive 1999/31/EC [2], any form of disposal of used tyres in natural environment has been completely banned since 2006 and, following this decision, the quantity of available used tyres has grown considerably. The waste disposal hierarchy has been set by Directive 2008/98/EC [3]. According to this hierarchy, the most recommended actions are:

- educe mass production of new waste

- recover the waste

- recycle the waste and use it as a raw material

- recycle the waste for power generation purposes

- dispose the unused waste in a safe and environmentally acceptable manner.

Recent data show that the quantity of waste tyres disposed in an uncontrolled manner has reduced considerably in Europe over the past decade, and that it now amounts to no more than 4 percent of the total quantity of waste tyres. At the same time, it is estimated that 29 percent of waste tyres (about 450,000 tor about 42.5 millions of tyres) are disposed of in an uncontrolled manner in new EU member countries. Tyre recycling belongs to the field of sustainable development as the recycling of used products results in valuable raw materials that can be used for manufacturing products with a new value. Three raw materials can be obtained by waste tyre recycling: a) rubber granules, b) steel fibres, and c) textile fibres (Figure 1).

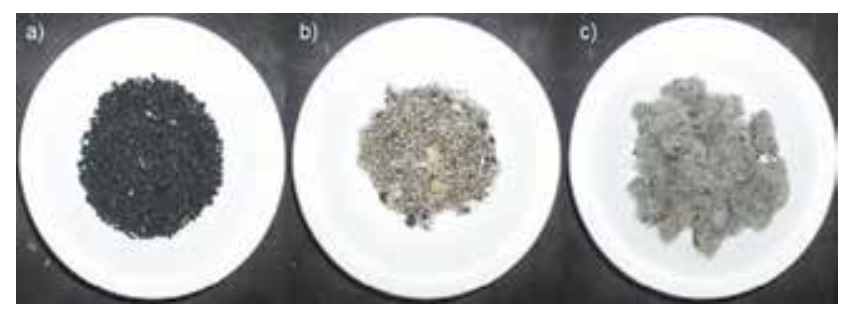

Figure 1. Products obtained by the automobile tyre recycling: a) rubber granules; b) steel fibres, and c) textile fibres

Only five percent of recycled waste tyres are currently used in construction industry, although the possibilities for such use are much greater in this field. That is why much effort has been invested in the development of new used tyre recycling technologies so that such recycled tyres can be reused as raw material in the production of new products. In recent times, rubber has found its use in cement industry, as a replacement agent in the production of surfaces for playfields and sports terrains, and as a component of various lining and covering products. In addition, one of new directions that has been studied over the past several years is the use of waste tyres and their components in the concrete manufacturing technology. The total of 1.5 billion tons of cement, 900 million litres of water, and 9 billion tons of sand and stone, are consumed each year for the production of concrete. In keeping with sustainability postulates, the main objective is to find alternative sources of raw products in concrete technology, as this would reduce an adverse environmental impact of production of concrete components, while at the same time preserving natural resources [6]. This is precisely why the products obtained by rubber recycling are considered as raw materials that are interesting for the production of special types of concrete.

Innovative construction products prepared with different raw materials obtained by waste tyre recycling are presented in this paper. All products were developed based on detailed original scientific research conducted at the Faculty of Civil Engineering, University of Zagreb. The results presented in the paper show that in some applications the concrete prepared with recyclates obtained from waste tyres are a promising economic and environmental alternative to traditional types of concrete.

\section{Use of rubber granulates}

\subsection{Influence of rubber granulates on concrete properties}

The following main features make the recycled tyre attractive for use in construction industry: low specific weight, low modulus of elasticity, insulating properties, and the capacity of absorbing energy when subjected to load. It is precisely because of these properties that new trends in the use of rubber in concrete are oriented toward development of products in which good use can be made of its insulating and absorbing properties [7, 8, 9], its capacity to absorb energy in high-strength concrete [10, 11], and as a replacement for chemical admixtures that are used for increasing resistance to freezing and thawing $[4,12]$.

The change of properties of rubberized concrete in fresh state depends on the size, proportion and texture of the rubber used in the preparation of concrete. One of advantages of the use of rubber as a replacement for some of the aggregate is the reduction in the density of concrete mix, because the density of rubber is much lower than the density of river aggregate or crushed aggregate. The density of fresh concrete made with natural aggregate amounts to $\sim 2400 \mathrm{~kg} / \mathrm{m}^{3}$, while the density of fresh concrete made with recycled rubber is lower and amounts to $1800-2100 \mathrm{~kg} / \mathrm{m}^{3}$. This means that that the density of concrete can be reduced by 20 to 30 percent if rubber is used instead of some of the aggregate, depending of course on the proportion of rubber in the concrete mix. Furthermore, the nonpolarity of rubber, and roughness of its surface, result in introduction of an additional quantity of air, namely because the nonpolar rubber rejects water and attracts air [13]. The addition of rubber to the fresh concrete mixture also results in a reduced workability, especially when greater proportions are added ( $>30 \%$ of the total volume of aggregate) [14, 15]. It can be seen in the diagram (Figure 2) that the density of concrete decreases by about $20 \%$ when rubber is added [16]. In addition, the workability of fresh concrete decreases and the air 
content increases with an increase in rubber content. Presented concretes have been prepared with a low water-cement ratio, and contain silica fume and superplasticiser, while the aggregate is replaced with rubber in proportions ranging from $5-15$ percent.

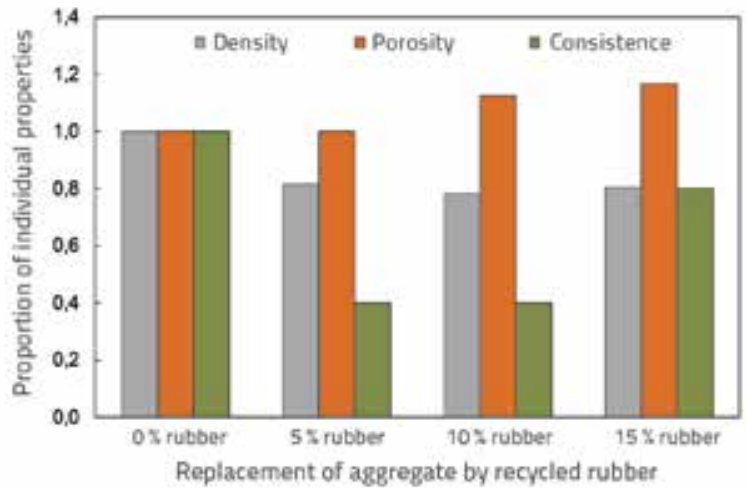

Figure 2. Influence of aggregate replacement with rubber on the density, air content, and consistency of fresh concrete

The replacement of aggregate with rubber reduces the compressive strength and stiffness in the composite, which could have been expected considering the physical and mechanical properties of rubber compared to stone aggregate [17, 27]. Normally, compressive action in concrete results in development of tensile stress which is localised around rubber particles in case of rubber-containing composites. This stress causes development of microcracks which propagate via cement matrix until the next rubber particle. Low elastic modulus of rubber, which is 25 to 25,000 times lower compared to that of the aggregate, enables considerable deformation of rubber in comparison with the usually used aggregate [18]. The capability of rubber to deform without failure when subjected to tensile stress makes the rubber act as a spring within the composite, which slows down further development of microcracks and full disintegration of the composite. Compared to ordinary concrete, the composite with rubber is characterized by ductile fracture, thanks to the capability of such composite to absorb significant quantity of plastic energy, and is consequently more ductile [17].

The capability of rubber to reject water, due to hydrophobicity of its surface, and consequent introduction of an additional quantity of air into the mixture, ensures a greater quantity of closed pores in the composite structure that are not available to water [24]. This is why these composites have a lower capability to absorb water by capillary absorption. Due to hydrophobicity of rubber, the absorbed water finds its way by bypassing rubber in order to advance, which slows down the process of penetration of water into the structure of the material. Reduced capillary absorption increases the durability of the composite and reduces the possibility of reinforcement corrosion, especially due to penetration of chlorides, which is why the use of this type of material in aggressive marine environments is becoming increasingly interesting [17]. Higher resistance of concrete to the penetration of chlorides can also be obtained by increasing the proportion of rubber in the composite [19], but also by making use of mineral admixtures such as silica fume, especially in case of smaller rubber proportions ( 5 percent of the total volume of aggregate, $0.1-3 \mathrm{~mm}$ ) [20]. Despite a lower capillary absorption, the presence of rubber particles causes higher penetration of water under pressure [16]. This is due to the poor quality of the rubber to cement matrix interface, but also to physical properties of rubber which 'shrinks" when subjected to high water pressure, thus allowing penetration of water under pressure [21].

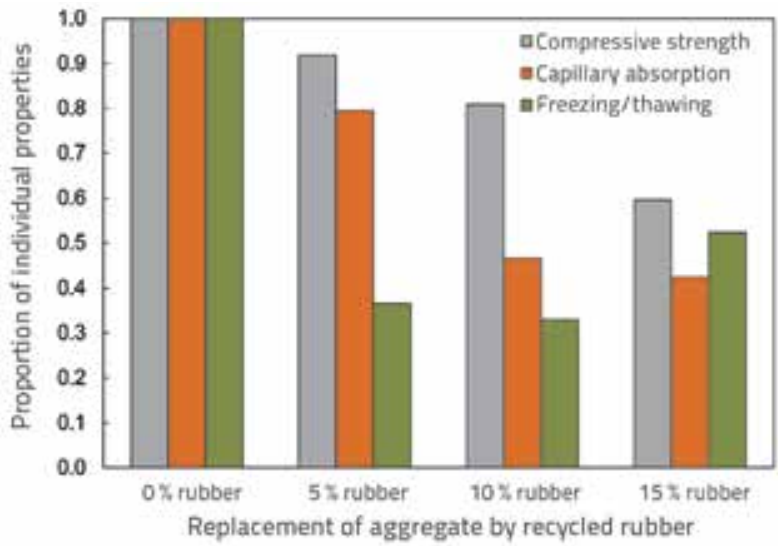

Figure 3. Influence of aggregate replacement with recycled rubber on the compressive strength, capillary absorption, and scaling due to freezing and thawing of hardened concrete

In addition to the above mentioned characteristics, one of basic properties that are significant for the utilisation of concrete is its resistance to freezing and thawing. Physical properties of rubber enable this material to behave as an absorber of internal stress due to hydrostatic pressure of water during the freezing and thawing cycle, which may be positive during the freezing cycle when the volume of water increases during conversion into ice [22].
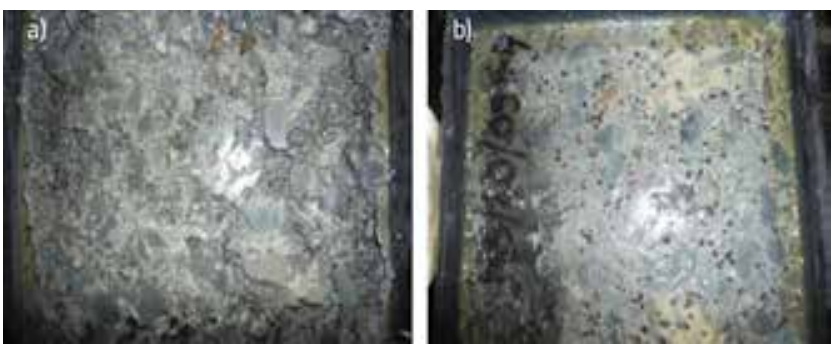

Figure 4. Structure of concrete without rubber: a) and when $10 \%$ of aggregate is replaced with rubber; b) after exposure to freezing and thawing cycles with deicing salt [23]

\subsection{Example of an innovative construction product - noise barrier}

As can be seen in regulations and directives applicable in the field of environmental protection, an exceptional importance is presently accorded to noise protection during design of transport infrastructure [25, 26]. Noise barriers used in Croatia prior to 2007 were made of wood, aluminium or transparent PVC, and were usually imported from other countries. In 
the period from 2007 to 2010, the noise absorbing concrete barriers fully developed and produced in Croatia, in accordance with trends prevailing in west European countries, have assumed the leading role in the sphere of noise protection. In Croatia, noise absorbing concrete barriers are now most often produced by adding expanded clay to the concrete. However, the production of expanded clay implies consumption of non renewable natural resources, and after such production the land remains barren and devastated. In addition, the production itself requires a certain quantity of energy, which is further complicated by emission of greenhouse gases. In addition to these environmental problems, it should be noted that Croatia does not have its own production of expanded clay, which represents an additional economic burden to barrier manufacturers.

Because of such problems with the existing concrete barrier solutions, the Faculty of Civil Engineering, University of Zagreb, has continued its research in the sphere of noise protection, in order to develop a solution that would be in harmony with principles of sustainable development. Using the insulating and absorptive properties of recycled rubber, the researchers developed concrete noise barriers whose absorptive layer is made of lightweight concrete to which rubber granules obtained by waste tyre recycling were added. These barriers were named RUCONBAR (Rubberized Concrete Noise Barriers) [28]. In its absorptive layer, RUCONBAR contains 40 percent of rubber granulates (Figure 5) obtained through a waste tyre recycling process, which is an innovative solution in the production of noise barriers, and is protected by patent rights granted by the State Intellectual Property Office of the Republic of Croatia (P20100483A).

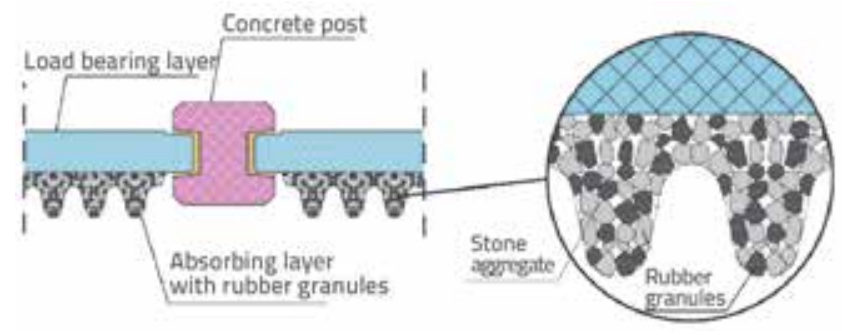

Figure 5. Cross-section of the innovative RUCONBAR solution [28]

The most important feature of the described noise barriers is their sound absorption property. In order to compare the sound absorption capability of the innovative material used for the development of RUCONBAR, appropriate laboratory samples were tested using the Kundt's tube, and real samples $10.0 \mathrm{~m}^{2}$ in area were used to conduct reverberation room tests (Figure 6) [29] in accordance with standards HRN EN ISO 354:2004 and HRN EN 1793-1:1999.

Based on results obtained during the testing, and in accordance with applicable standards, the RUCONBAR barrier was classified in the sound absorption category $A 3$ based on the single number sound absorption rating of $\mathrm{DLa}=8.7$ $\mathrm{dB}$. In addition to extremely good ad competitive sound absorption properties, the RUCONBAR barrier has several other outstanding durability properties such as an excellent resistance to freezing and thawing and a remarkable fire resistance. The significance of concrete barriers for noise protection, with an absorbing layer of recycled rubber, has also been recognised by the European Union. Thus the RUCONBAR project is co-financed by the EU in the scope of the ECO innovation initiative, via the European Agency for Competitiveness and Innovation (EACI). The RUCONBAR project, formed of Croatian partners only, is based on two companies, Gumiimpex GRP, which produces the rubber recyclate, and Beton Lučko, which produces the RUCONBAR barriers. The company Institut IGH, in its capacity as partner, tests sound and insulation properties of the barrier, as well as other properties that are significant for the durability and bearing capacity of RUCONBAR barriers. The objective is to form a manufacturing line for the production of noise barriers containing recycled rubber granules, and to successfully establish RUCONBAR barriers on the noise barrier market.

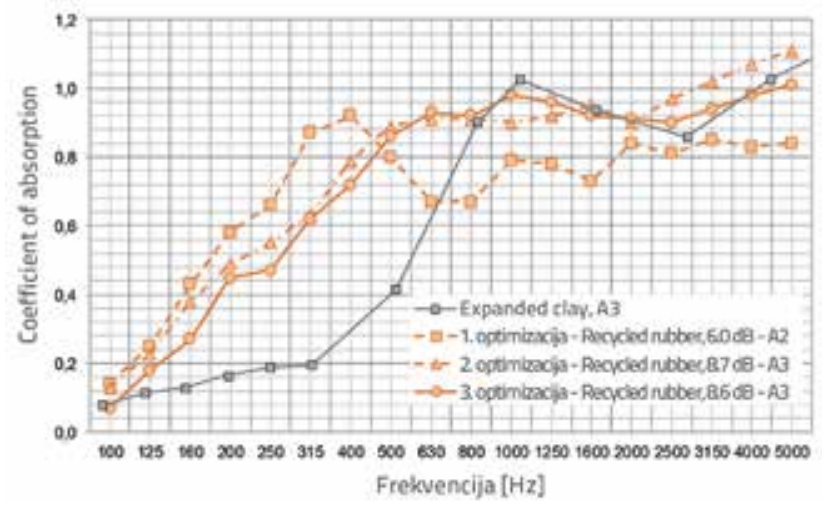

Figure 6. Acoustic testing on small specimens

\section{Fibre reinforced concrete with recycled steel fibres}

\subsection{Influence of steel fibres on concrete properties}

When added to concrete, steel fibres improve its quality by increasing its energy absorption capacity. Thanks to the capacity of these fibres to transfer load from the damaged to undamaged parts of the cross section, the fibre reinforced concrete is characterised by lower brittleness compared to ordinary concrete [30]. The capacity of fibres to limit propagation of cracks is the basic parameter that extends the structure's life span and cuts down maintenance costs simply because the occurrence of cracks on the concrete surface exposed to weather and other impacts greatly affects life span of concrete structures.

Steel and textile fibres of various dimensions and quality are formed during recycling of waste tyres. Steel and textile fibres obtained by waste tyre recycling are presently used to a lesser extent compared to the recycled tyre itself. Recycles steel fibres (Figure 7) can for instance be used in civil engineering as a less 

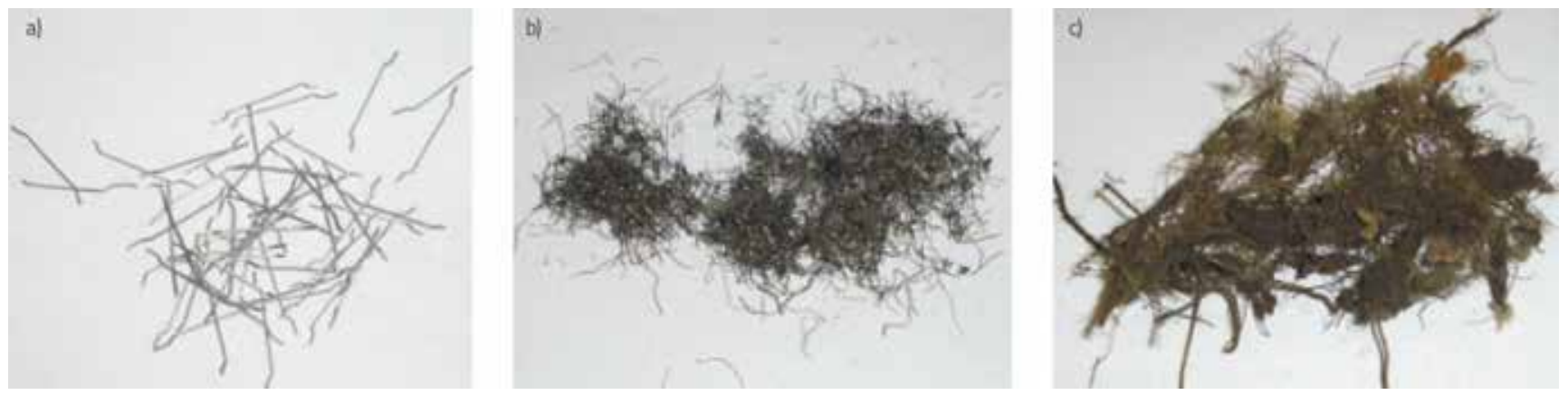

Figure 7. Steel fibre types used in fibre reinforced concrete: a) industrial fibres; b) fibres recycled from automobile tyres, purified; c) fibres recycled from automobile tyres, non-purified

costly alternative to industrial steel fibres: in prefabricated elements, shotcrete used for protecting excavation of steep slopes and underground works, airport runways, and industrial floor systems. In Europe, the current demand for reinforcement amounts to about 12 million tons annually [31]. At that, it should be noted that, due to considerable demand, the price of steel continuously rises, particularly in China, and now stands at about $€ 700$ per ton. Despite its good characteristics, the fibre reinforced concrete occupies a very small fragment of the market namely because the demanding fibre production technology greatly increases the price per cubic metre of concrete. Currently the price of industrial fibres is almost 10 times as great as price of recycled fibres. Based on the data from 2004 [31], and assuming a uniform growth of the market, the quantity of recycled fibres from waste tyres is more than sufficient for meeting the needs of the market. Studies conducted so far to define possibilities for the use of steel fibres from waste tyres have revealed several positive features of this material [32, 33, 34]. In fact, recycled fibres are an economically and environmentally justified alternative to industrial fibres, especially when used in greater proportions and if mixed with industrial fibres [39]. They limit propagation of cracks and increase toughness of the composite compared to ordinary concrete, even in case of separation and pulling out of the composite [38]. If recycled steel fibres are used in the amount of two percent of the total mass of the composite, this results in significant improvement of the resistance to fatigue, when compared to ordinary concrete [39].

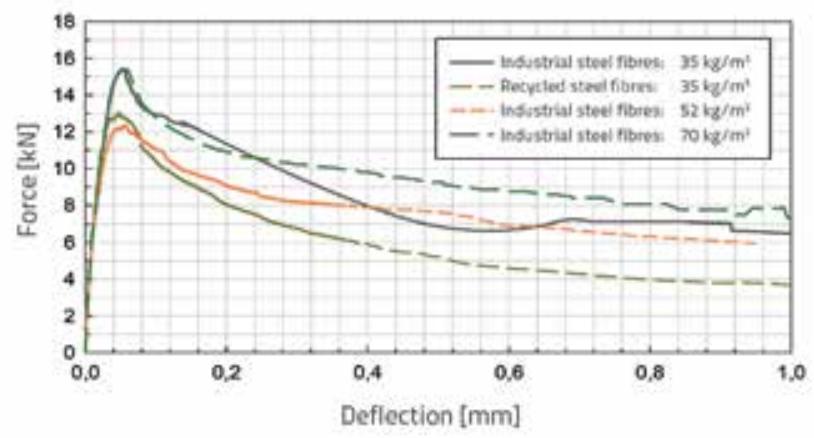

Figure 8. Working diagram of fibre reinforced concretes containing different types and quantities of steel fibres during ductility testing
A comparison of fibre reinforced concrete containing industrial fibres, with fibre reinforced concrete containing the same and higher quantity of recycled fibres obtained by automobile tyre recycling, is presented in form of diagram in Figure 8. This diagram shows that the design of mixes with recycled fibres results in properties that are similar to those of mixes prepared with industrial fibres.

In addition to its influence of ductility, the introduction of steel fibres in fibre reinforced concrete can result in some other benefits. Preliminary research (Figure 9) has revealed that fibre reinforced concrete mixes prepared with cleaned steel fibres are characterized by lower incidence of scaling when subjected to freezing and thawing cycles [33]. In addition, it was established that such fibre reinforced concrete is less susceptible to wearing and corrosion when exposed to aggressive marine environment [35, 36].

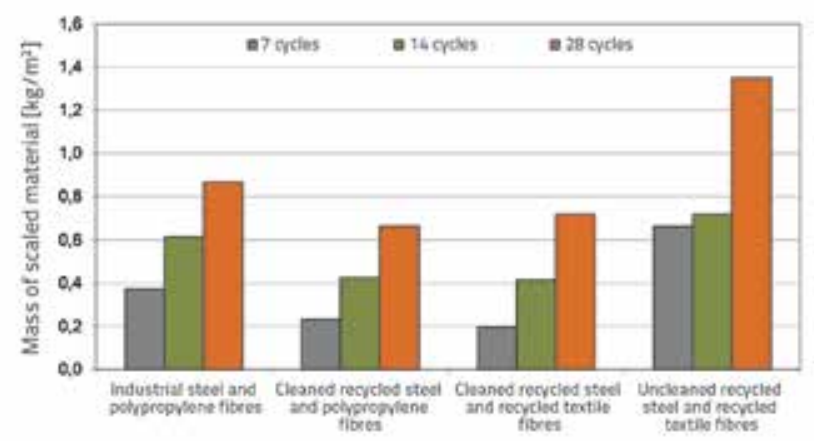

Figure 9. Mass of material scaled when concrete containing different types of fibres was exposed to freezing and thawing cycles

\subsection{Example of an innovative construction product - hybrid fibre reinforced concrete}

Fibre reinforced concrete can also extensively be used for fabrication of a number of prefabricated elements in cases where a considerable resistance to bending, and also to dynamic and impact load, is required. One of such prefabricated elements are railway tracks on concrete bedding [37]. Extensive international experience with tracks on solid bedding has shown that their durability is greatly dependent on their installation. In fact, the quality of the design mix, and the way in which 
the mix is placed and cured, may greatly define occurrence of cracks during subsequent use of such elements. It is also very significant to take into account the shrinkage of concrete. Considerable shrinkage of concrete may result in cracking after realization of the track (Figure $10 \mathrm{a}$ ). The problem of fracturing at the level of concrete block supports under twin block sleepers has also been registered. Such fracturing occurs due to long-term stress during use of the tracks (Figure $10 \mathrm{~b}$ ). This is precisely why it has become increasingly clear that efforts must be made to develop the type of concrete that would be resistant to impacts and dynamic loads, and less susceptible to cracking due to shrinkage..
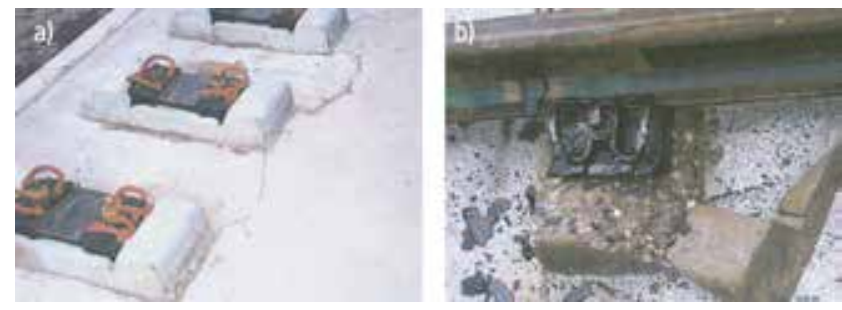

Figure 10. Degradation on rail tracks: a) cracking due to concrete shrinkage; b) damage to rail supports, [42]

An extensive research of possible uses of recycled steel fibres in production of the hybrid fibre reinforced concrete $H M A B$, $[40,41,42,43,44,45,46,47,48]$ has been conducted in the scope of the ECOTRACK project - Track on concrete bedding. In cooperation with partners from the industry, i.e. Viadukt d.d. (TBP Pojatno) and Gumiimpex-GRP d.o.o., and with financial backing from the BICRO (Business Innovation Croatian Agency), the total of twenty concrete mixtures were analysed and, at that, sixteen mechanical and durability properties of HMAB were tested on more than 1200 samples.

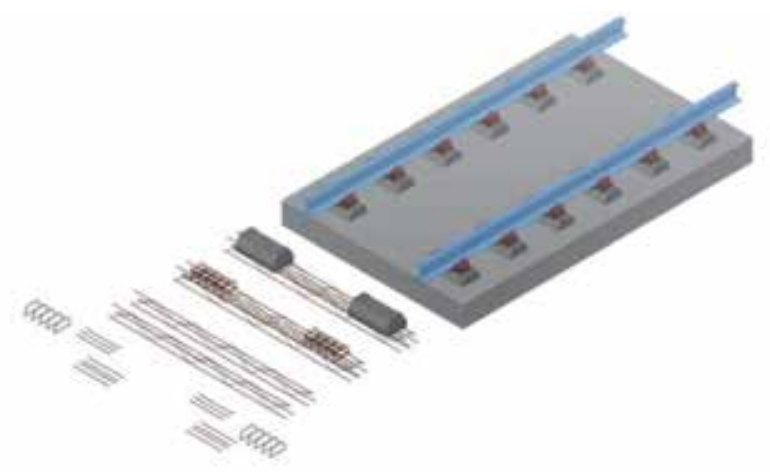

Figure 11. Conceptual prototype of Ecotrack [41]

ECOTRACK is an innovative environmental product consisting of a modern railway track on concrete bedding without ballast (Figure 11). The product is composed of twin concrete sleepers installed in the concrete bedding, and so the two form a solid concrete track structure. The innovativeness of the product lies in the use of a waste tyre recycling product in the concrete of twin sleepers and the load bearing concrete bedding, as a replacement for a part of natural raw materials.
The analysis of the recycled fibre composite's resistance to fatigue has revealed that, when subjected to loading, the industrial and recycled fibres become active in different phases: industrial fibres actively participate in bypassing macro-cracks while the efficiency of recycled fibres is much greater in case of micro-cracks and midsize-cracks [40]. Taking into account basic postulates for the design of hybrid fibre reinforced concrete, and based on research results, it can reasonably be concluded that the combination of the two types of fibres, industrial and recycled, would be an ideal means for proper strengthening of brittle composites. In this case, recycled fibres would prevent transition of micro-cracks into midsize cracks and would contribute, together with industrial fibres, to the prevention of transition from midsize cracks into macrocracks. Even if macro-cracks should occur, the transfer of load from the damaged to the undamaged part of the cross-section would be ensured by industrial fibres.

The contribution of individual types of fibres to concrete properties was quantified by varying recycled steel fibre proportions (0\%, $50 \%$, and $100 \%)$ without changing the total quantity of fibres $\left(30 \mathrm{~kg} / \mathrm{m}^{3}\right)$ in concrete. An irregular shape and size of recycled fibres contributes to a lower energy absorption capability but, at the same time, the synergy of the two types of fibres was registered in that the hybrid composites behave mch better after the first occurrence of cracks, when compared to the composite consisting of recycled fibres only (Figure 12).

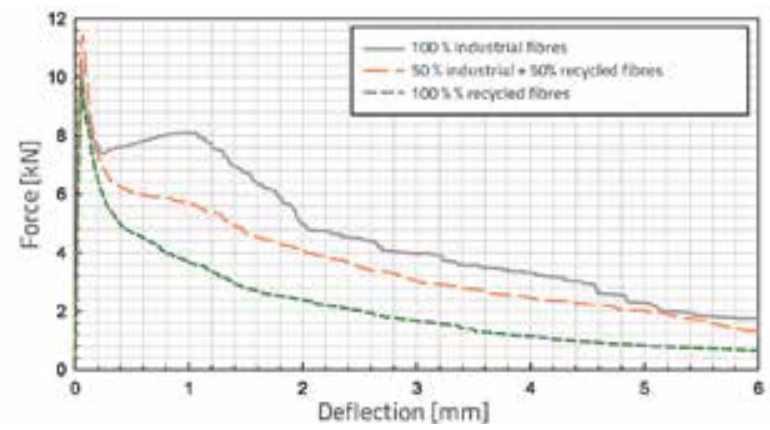

Figure 12. Influence of the recycled steel fibre content on the resistance of concrete to bending load

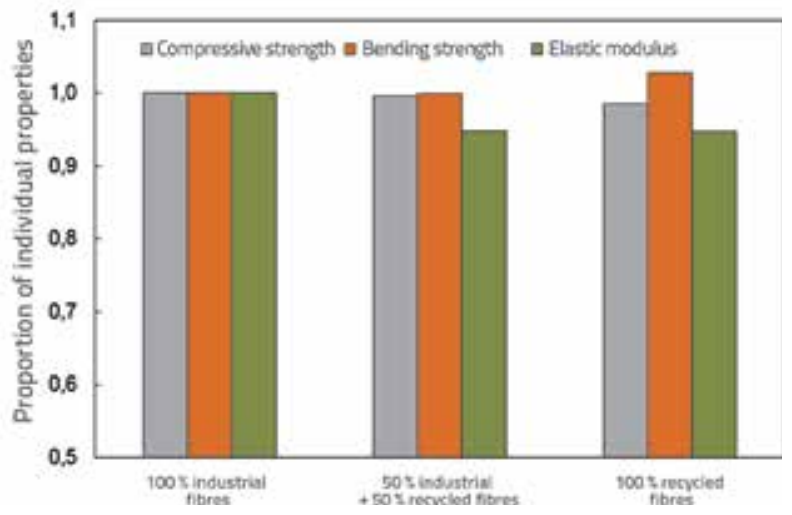

Slika 13. Influence of the recycled steel fibre content on the compressive strength, tensile strength, and elastic modulus 
As the replacement of industrial fibres with recycled fibres does not affect other mechanical properties of fibre reinforced concrete, such as the compressive strength, tensile strength, and elastic modulus (Figure 13), while the post-cracking behaviour of concrete actually improves with such replacement, it can be concluded that recycled fibres can be used, in an appropriate proportion, as a welcome alternative to the industrially produced fibres.

\section{Textile fibres}

\subsection{Influence of recycled textile fibres on concrete properties}

The last product of waste tyre recycling are textile fibres (Figure 14a). These fibres have not so far found their use in construction industry. Polypropylene fibres are often used in concrete (Figure $14 \mathrm{~b}$ ) in order to prevent crack initiation due to autogenous shrinkage and shrinkage caused by drying. As dimensions of textile fibres obtained by waste tyre recycling are similar to dimensions of polypropylene fibres, a concept involving replacement of industrial fibres with fibres obtained by waste tire recycling has been developed.
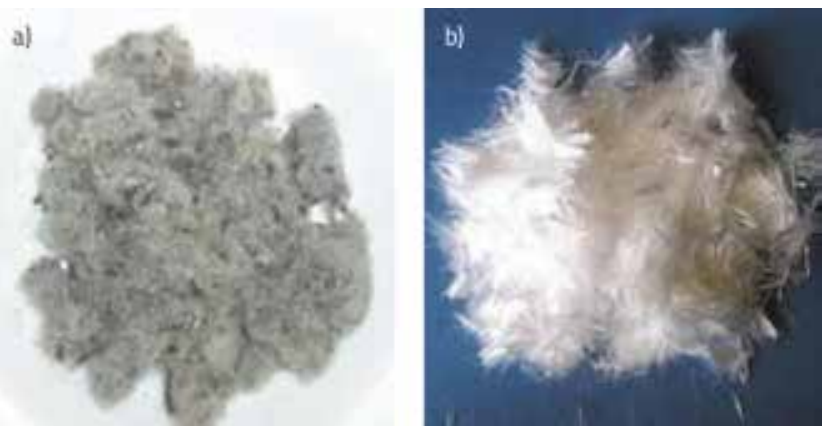

Figure 14. Types of polymer fibres: a) recycled textile fibres from car tyres; b) industrial polypropylene fibres

Preliminary research has shown that the influence of recycled textile fibres on the reduction of shrinkage due to drying is similar to that of industrial polypropylene fibres (Figure 15) [48]. If an increase in deformation due to concrete drying is compared with values for the same concrete without fibres, calculated according

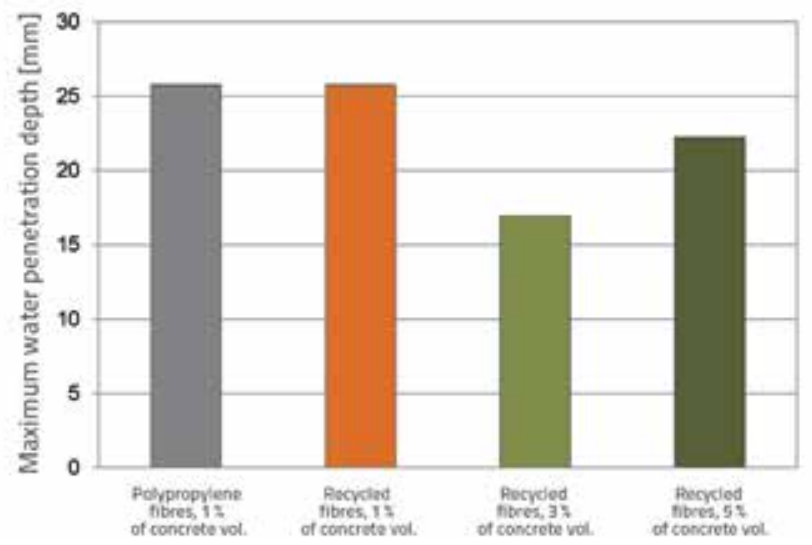

to Eurocode 2, it can be seen that the reduced shrinkage can be observed in the first days of the concrete matrix hardening process. Micro-cracking most often occurs precisely in these first days and so proper cure is of crucial significance in this period. When such recycled fibres are used, the concrete shrinkage is visibly reduced, and hence the risk of cracking due to improper or insufficient curing is also lowered.

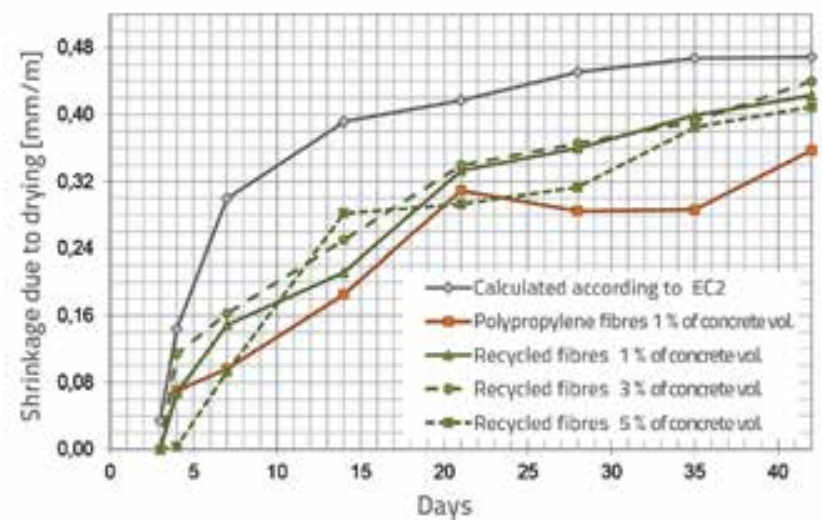

Figure 15. Shrinkage due to drying calculated according to Eurocode 2 for ordinary concrete, and measured for the same concrete prepared with different proportions of textile fibres

In addition to reduced shrinkage due to drying, the recycled textile fibres have also some other positive influences on concrete durability. The research conducted at the Faculty of Civil Engineering shows that the concrete prepared with recycled polymer fibres has a higher resistance to penetration of chlorides and a reduced penetration of water (Figure 16) [48]. These results show that recycled textile fibres obtained from waste automobile tyres can be used for the preparation of concrete. It would especially be interesting to use such fibres for preparation of repair mortars, where it is extremely important to prevent occurrence of micro-cracks and penetration of aggressive substances, so as to meet the planned and specified durability requirements set for existing structures. In addition to this use, the oncoming research will be oriented toward possible use of this type of concrete in the industry of prefabricated elements.

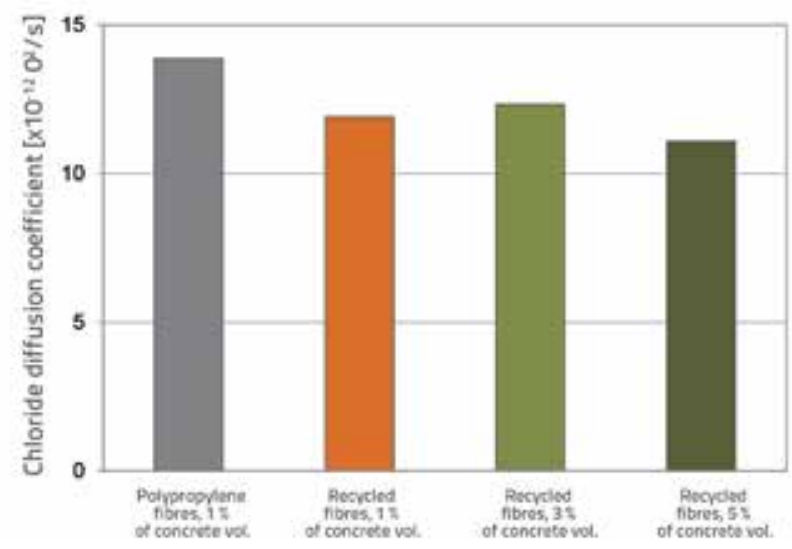

Figure 16. Penetration of water under pressure and chloride penetration coefficient for concrete prepared with different volume proportions of textile fibres 


\section{Conclusion}

Three types of materials are obtained in the waste tyre recycling process: rubber granulates, steel fibres, and polymer fibres. The way in which concrete properties are influenced by each of these materials, when used as secondary raw materials, is explained in the paper. Taking into account properties obtained in the research, special-purpose construction products have been developed at the Faculty of Civil Engineering in Zagreb. These special products contain raw materials obtained by tyre recycling and they make use of specific properties of such secondary raw materials in order to provide an added value to construction products.

Rubber granules reduce compressive strength of concrete but, at the same time, they increase resistance to freezing and thawing, and the sound absorption capability. These very properties have been used in the preparation of the RUCONBAR sound barrier. On the other hand, the addition of recycled steel fibres increases ductility of concrete, and prevents propagation of cracks. These properties have been used in the preparation of an innovative hybrid fibre reinforced concrete that presents exceptional environmental and economic advantages. The addition of textile fibres reduces deformations due to shrinkage, and positively influences durability properties of concrete, and hence this material is becoming an interesting raw material for the preparation of mortars.

\section{REFERENCES}

[1] ETRMA - European tyre and rubber manufacturers association "End of life tyres - A valuable resource with growing potential", 2010.

[2] Council of the European Union, "Council Directive 1999/31/EC of 26 April 1999 on the land fill of waste," 1999.

[3] Council of the European Union, "Council Directive 2008/98/EC on waste (Waste Framework Directive)

[4] Bjegović, D., Lakušić, S., Serdar, M., Baričević, A.: Properties of concrete with components from waste tyre recycling, $6^{\text {th }}$ Central European Congress on Concrete Engineering Marianske Lazne, Czech Republic, 30 ${ }^{\text {th }}$ September - 09 ${ }^{\text {th }}$ October 2010., pp.134140.

[5] Mehta, P.K.: Concrete Technology for Sustainable Development Concretelnternational (1999), Vol.21, No. 11, pp. 47-53

[6] Bjegović, D., Serdar, M., Jelčić Rukavina, M., Baričević, A. Istraživanja kriterija održivosti armiranog betona. GRAĐEVINAR (2010) 62, 10; pp. 931-940

[7] Lakušić, S., Bjegović, D., Baričević, A., Haladin, I., Serdar, M.: Apsorpcijska svojstva laganog betona s recikliranom gumom RUCONBAR, Međunarodni simpozijum o istraživanjima i primeni savremenih dostignuća u građevinarstvu u oblasti materijala i konstrukcija, Tara, Srbija, 19-21 October 2011, pp. 73-80.

[8] Lakušić, S., Bjegović, D., Serdar, M., Baričević, A.: ECOBAR betonske barijere za zaštitu od buke - inovativno rješenje, Ekološki problemi prometnog razvoja, Zagreb, pp. 123-131, 2011.
Because of its characteristics, each of these innovative materials may be used as an environmentally, functionally and economically competitive alternative to products that are nowadays dominantly used in the engineering practice. Most of products presented in the paper have also been recognised by national and international institutions whose task is to encourage innovation and sustainability in all industries, which has enabled the use of these products outside of laboratory conditions and scientific community.

\section{Acknowledgement}

The research presented in this paper was conducted in the scope of two national research projects financed by the Ministry of Science, Education and Sport: 82-0822161-2159 and 0820000000-2185. The project "Rubberized Concrete Noise Barriers", RUCONBAR ECO/10/277317, was financed by the European Commission in the scope of the ECO innovation initiative, via the European Agency for Competitiveness and Innovation (EACI). The ECOTRACK project was financed by the BICRO agency in the scope of the Proof of Innovative Concept initiative. The authors extend their thanks to participants in the above projects as without them the scientific research presented herein would not have been implemented. Special thanks are extended to the companies that have continuously supported research undertaken in this area: Viadukt d.d (TBP Pojatno), Gumiimpex GRP d.o.o., Beton Lučkod.o.o.and Holcim Croatia.

[9] Biliškov, H.: Optimizacija betona s recikliranom gumom / diplomski rad. Zagreb, Građevinski fakultet, 03.12. 2009, 120 str. (voditelj: Bjegović, D., neposredni voditelj: Serdar, M.)

[10] Bjegovic, D., Baricevic, A., Lakusic, S.: Rubberized hybrid fibre reinforced concrete, International Conference Microstructural - related Durability of Cementitious Composites, RILEM Proceedings PRO 83. Amsterdam: Rilem Publications s.a.r.l., 2012.

[11] Bjegovic, D.,Baricevic, A., Lakusic, S.: Innovative low cost fiberreinforced concrete. Part I: Mechanical and durability properties, 3rd International Conference on Concrete Repair, Rehabilitation and Retrofitting, CRC Press/Balkema,2012.

[12] Lakušić, S., Bjegović, D., Serdar, M.: Primjena reciklirane gume na prometnicama, Prometnice - nove tehnologije i materijali, Građevinski fakultet Sveučilišta u Zagrebu, Zavod za prometnice, 2010., str. 7-46.

[13] Siddique, R., Naik, T.R.: Properties of concrete containing scraptire rubber - an overview, Waste management (2004), vol. 24, no. 6, pp. 563-569.

[14] Nehdi M., Khan, A.: Cementitious Composites Containing Recycled Tire Rubber: An Overview of Engineering Properties and Potential Applications, Cement, concrete and aggregates (2001), vol. 23, no. 1, pp. 3-10.

[15] Cairns, R., Kew, H.Y., Kenny, M.J.: The Use of Recycled Rubber Tyres in Concrete Construction, Final Report, University of Strath clyde, Glasgow, UK, 2004 
[16] Pezer, M., Alibegić, M.: Ekološki beton s recikliranom gumom, Dekanova nagrada, Zagreb, Građevinski fakultet, 2010. (voditelj: Bjegovič, D., neposredni voditelji: Baričevič, A.)

[17] Benazzouk, A., Douzane, O., Langlet, T., Mezreb, K., Roucoult, J., \& Queneudec, M.: Physico-mechanical properties and water absorption of cement composite containing shredded rubber wastes. Cement and Concrete Composites (2007), 29(10), pp. 732-740.

[18] Khorami, M., Ganjian, E., Vafaii, A.: Mechanical Properties of Concrete with Waste Tire Rubbers as Coarse Aggregates. Proceeding of Special sections on International conference on Sustainable Construction Materials and Technologies (pp. 8590). Coventry University, 2007.

[19] Oikonomou, N., Mavridou, S.: Improvement of chloride ion penetration resistance in cement mortars modified with rubber from worn automobile tires. Cement and Concrete Composites (2009), 31(6), pp. 403-407.

[20] Gesoğlu, M., Güneyisi, E.: Strength development and chloride penetration in rubberized concretes with and without silica fume. Materials and Structures (2007), 40(9), pp. 953-964.

[21] Ganjian, E., Khorami, M., Maghsoudi, A.A.: Scrap-tyre-rubber replacement for aggregate and filler in concrete. Construction and Building Materials (2009), 23(5), pp. 1828-1836.

[22] Skripkiūnas, G., Grinys, A., Janavičius, E.: (2010). Porosity and Durability of Rubberized Concrete. http://www.claisse. info/2010\%20papers/m55.pdf

[23] Beus, J.: Utjecaj reciklirane gume kao zamjene agregatu na svojstva betona / diplomski rad. Zagreb : Gradevinski fakultet, 03.12. 2009, 80 str. (voditelj: Bjegović, D., neposredni voditelj: Serdar, M.)

[24] Čović, M. Optimalizacija svojstava morta s različitim udjelima reciklirane gume / završni rad - preddiplomski studij. Zagreb, Građevinski fakultet, 11.09. 2012, 61 str. (voditelj: Bjegović, D., neporedni voditelj: Baričević, A.)

[25] Lakušić, S., Dragčević, V., Rukavina, T.: Mjere za smanjenje buke od prometa u urbanim sredinama. GRADEVINAR 57 (2005), 1; pp. 1-9

[26] Lakušić, S., Dragčević, V., Rukavina, T.: Pregled europske regulative o buci od cestovnog prometa, GRADEVINAR 55 (2003), 6; pp. 349-356

[27] Bjegović, D., Baričević, A., Serdar, M.: Durability properties of concrete with recycled waste tyres, 12th International Conference on Durability of Building Materials and Components Porto, Faculdade de Engenharia Universidade do Porto, 2011. pp. 1659-1667

[28] EU Projekt "Rubberized Concrete Noise Barriers", RUCONBAR ECO/10/277317, www.ruconbar.com

[29] Kušević,I.,Franolić,Z::"Apsorbirajućii betonskipaneli-Usporedba ispitivanja zvučne apsorpcije", Institut građevinarstva Hrvatske (IGH), Zagreb, 2010.

[30] Seferović, E.: Primjena čeličnih vlakana u primarnoj podgradi tunela, GRAĐEVINAR 54 (2002) 8; pp. 473-478

[31] Pilakoutas, K., Neocleous, K., Tlemat, H.:Reuse of tyre steel fibres as concrete reinforcement. Proceedings of the ICE: Engineering Sustainability (2004), 157(3), 131-138.

[32] Neocleous, K., Angelakopoulos, H., Pilakoutas, K., Guadagnini, M.: Fibre - reinforced roller-compacted concrete transport pavements. Proceeding of the ICE - Transport (2011), 164(2), 97-109.

[33] Marasović, I.: Utjecaj mikroarmiranja recikliranim vlaknima na svojstva betona / diplomski rad. Zagreb : Gradevinski fakultet, 03.12.2009, 120 str. (voditelj: Bjegović, D., neposredni voditelj: Serdar, M.)
[34] Zadro, A.; Jurić, K.: Ekološki reciklirani mikroarmirani betoni, Dekanova nagrada, Zagreb, Gradevinski fakultet, 2010. (voditelj: Bjegovič, D., neposredni voditelji: Serdar, M., Baričević, A.)

[35] Mokos, l.: Procjena trajnosti mikroarmiranih betona u morskom okolišu primjenom potenciostatske anodne polarizacije / završni rad - diplomski/integralni studij. Zagreb : Gradevinski fakultet, 14.02.2013, 87 str. (voditelj: Bjegović, D., neposredni voditelj: Baričević, A.)

[36] Kovačević, J.: Promjena svojstava recikliranog hibridnog mikroarmiranog betona uslijed izloženosti agresivnom okolišu / završni rad - diplomski/integralni studij. Zagreb, Građevinski fakultet, 14.02.2013, 68 str. (voditelj: Bjegović, D., neposredni voditelj: Baričević, A.)

[37] Lakušić, S., Vajdić, M.: Pregled suvremenih kolosiječnih konstrukcija na čvrstim podlogama. GRAĐEVINAR 63 (2011) ; pp. 125-134

[38] Tlemat, H., Pilakoutas, K., Neocleous, K.: Stress-strain characteristic of SFRC using recycled fibres. Materials andStructures (2006), 39, 365-377.

[39] Achilleos, C., Hadjimitsis, D., Neocleous, K., Pilakoutas, K., Neophytou, P. O., Kallis, S.: Proportioning of Steel Fibre Reinforced Concrete Mixes for Pavement Construction and Their Impact on Environment and Cost. Sustainability (2011), 3(7), 965-983.

[40] Graeff, A. G., Pilakoutas, K., Neocleous, K., Peres, M. V. N. $\mathrm{N}$.: Fatigue resistance and cracking mechanism of concrete pavements reinforced with recycled steel fibres recovered from post-consumer tyres, Engineering Structures (2012), vol. 45, pp. 385-395.

[41] Lakušić, S., Bjegović, D., Baričević, A., Haladin, I.: Betoni visokih uporabnih svojstava kod kolosijeka za velike brzine. Međunarodni simpozijum o istraživanjima i primeni savremenih dostignuća u građevinarstvu u oblasti materijala i konstrukcija, Tara, Srbija, 19-21 October 2011, pp. 81-88.

[42] Bjegovic, D., Baricevic, A., Lakusic, S.: Mechanical properties of high strength concrete with recycled steel fibres from waste tyres. 8th RILEM International symposium on fibre reinforced concrete: Challenges and Opportunities (BEFIB 2012). Guimarães, Portugal, 2012.

[43] Lakušić, S., Baričević, A., Damjanović, D., Duvnjak, I., Haladin, I.: Kolosijek na betonskoj podlozi - ECOTRACK, Građenje prometne infrastrukture (ur. Lakušić, S.), Građevinski fakultet Sveučilišta u Zagrebu, Zavod za prometnice, 2012, pp. 7-49.

[44] Lakušić, S., Bjegović, D., Baričević, A., Haladin, I.: Innovative materials for sustainable railway tracks, 2nd International Conference on Road and Raill nfrastructure, Dubrovnik, 7-9 May 2012, pp. 675-682

[45] Bjegović, D., Baričević, A., Lakušić, S., Damjanović, D., Duvnjak, l.: Positive interaction of industrial and recycled steel fibres in fibre reinforced concrete. Journal of Civil Engineering and Management (2012). (prihvaćen za objavljivanje).

[46] Pezer, M.: Mehanička svojstva betona mikroarmiranih recikliranim čeličnim vlaknima / završni rad - diplomski/ integralni studij. Zagreb: Građevinski fakultet, 23.02. 2012, 91 str. (voditelj: Štirmer, N., neposredni voditelj: Baričević, A.)

[47] Jurić, K.: Upotreba recikliranih čeličnih vlakana za proizvodnju mikroarmiranih betona / završni rad - preddiplomski studij. Zagreb, Građevinski fakultet, 13.09. 2011, 71 str. (voditelj: Bjegović, D., neposredni voditelj: Baričević, A.)

[48] Petti, K., Marinac, L.: Betoni s otpadnim tekstilnim vlaknima, Dekanova nagrada, Zagreb, Građevinski fakultet, 2010., (voditelj: Bjegović, D., neposredni voditelj: Baričević, A.) 